\title{
EFEKTIFITAS PELATIHAN KETERAMPILAN BERUSAHA DAN BANTUAN STIMULAN USAHA EKONOMIS PRODUKTIF TERHADAP PENGENTASAN KEMISKINAN (STUDI KASUS DI KOTA BANJAR)
}

\author{
Maman Sulaeman \\ Politeknik Triguna Tasikmalaya \\ Email: mamansulaeman93@gmail.com
}

\begin{abstract}
Poverty is still a big and complex problem caused by social, cultural, political and economic conditions and interactions. Therefore, poverty reduction strategies and programs require an integrated approach, and their implementation is done gradually, planned and sustainable. The specific purpose of this research is to know the effectiveness of business skill training and stimulant aid of productive economic effort in poverty alleviation in Banjar City. This research uses survey method with sample number 94. Partial test result and simultaneous training of effort skill and economic effort productively effective in poverty alleviation.
\end{abstract}

Keywords: poverty, skill, stimulant aid, economical

\begin{abstract}
Abstrak Kemiskinan masih merupakan masalah besar dan kompleks yang ditimbulkan oleh kondisi dan interaksi sosial, budaya, politik dan ekonomi. Oleh karenanya strategi dan program penanggulangan kemiskinan memerlukan pendekatan yang terpadu, dan pelaksanaannya dilakukan secara bertahap, terencana dan berkesinambungan. Tujuan khusus penelitian ini adalah untuk mengetahui efektifitas pelatihan keterampilan berusaha dan bantuan stimulan usaha ekonomis produktif dalam pengentasan kemiskinan di Kota Banjar. Penelitian ini menggunakan metode survey dengan jumlah sampel 94. Hasil pengujian secara parsial dan simultan pelatihan keterampilan berusaha dan bantuan usaha ekonomis produktif efektif dalam pengentasan kemiskinan.
\end{abstract}

Kata Kunci: kemiskinan, keterampilan, bantuan stimulan, ekonomi

\section{PENDAHULUAN}

Kemiskinan merupakan salah satu masalah yang selalu dihadapi oleh manusia. Kemiskinan sebagai suatu permasalahan sosial ekonomi tidak hanya dialami oleh negara-negara yang sedang berkembang (developing countries) saja, tetapi juga negara-negara maju (developed countries) seperti Amerika Serikat dan Inggris. Inggris mengalami kemiskinan di penghujung tahun 1700-an pada era kebangkitan revolusi yang muncul di Eropa. Persoalan kemiskinan menarik untuk disimak dari berbagai aspek, yaitu aspek sosial, ekonomi, psikologi dan politik. Aspek sosial terutama akibat terbatasnya interaksi sosial dan penguasaan informasi. Aspek ekonomi akan tampak pada terbatasnya pemilikan alat produksi, upah kecil, daya tawar rendah, tabungan nihil, lemah mengantisipasi peluang. Dari aspek psikologi adalah rasa rendah diri, fatalisme, malas, dan rasa terisolir. Sedangkan dari aspek politik berkaitan dengan kecilnya akses terhadap berbagai fasilitas dan kesempatan, diskriminasi, posisi lemah dalam proses pengambilan keputusan. Sebagian kalangan yang melihat sebagai isu politik, bahwa kemiskinan disebabkan karena kebijakan politik yang salah yang melahirkan ketidakadilan sosial dan lemahnya kesempatan memperoleh pendidikan (Schumacher dalam Sadu Wasistiono, 2006:3).

Di Indonesia angka garis kemiskinan ditetapkan melalui indikator ekonomi, yaitu dari ukuran rata-rata kemampuan masyarakat untuk dapat memenuhi kebutuhan hidup minimumnya. Melalui pendekatan sosial masih sulit mengukur garis kemiskinan masyarakat, tetapi dari indikator ekonomi secara teoritis dapat dihitung dengan menggunakan tiga pendekatan, yaitu pendekatan produksi, pendapatan, dan pengeluaran. Sementara ini yang dilakukan oleh BPS untuk mengukur garis kemiskinan adalah pendekatan pengeluaran.

Kemiskinan harus segera ditanggulangi karena merupakan kewajiban moral, sosial, hukum maupun politik bagi bangsa Indonesia bahkan sudah merupakan komitmen antara pemerintah Indonesia dan 188 negara lainnya di 
dunia dalam Deklarasi Millenium Persatuan Bangsa-Bangsa yang dikenal dengan Millenium Development Goals (MDGs), dimana salah satunya adalah "menanggulangi kemiskinan dan kelaparan" dengan target menurunkan proporsi penduduk yang tingkat pendapatannya di bawah USD 1/hari menjadi setengahnya antara tahun 1990-2015, dan menurunkan proporsi penduduk yang menderita kelaparan menjadi setengahnya antara tahun 1990-2015.

Penanggulangan kemiskinan di Indonesia telah banyak dilakukan oleh pemerintah melalui berbagai program dan kegiatan dengan melibatkan berbagai departemen/lembaga pemerintah. Bahkan pemerintah telah mengeluarkan kebijakan berupa Peraturan Presiden Nomor 54 Tahun 2005 tentang Tim Koordinasi Penanggulangan Kemiskinan. Program-program dimaksud, diantaranya Program Nasional Pemberdayaan Masyarakat (PNPM) Mandiri yang merupakan kelanjutan dari P2KP dan PPK, Program Keluarga Harapan (PKH), Kredit Usaha Rakyat (KUR), Tabungan Keluarga Sejahtera (TAKESRA), Kredit Usaha Keluarga Sejahtera (KUKESRA), Asuransi Kesehatan Keluarga Miskin (Askeskin) yang dilanjutkan dengan Jaminan Kesehatan Masyarakat (Jamkesmas) dan oleh pemerintah daerah ditindaklanjuti menjadi Jaminan Kesehatan Daerah (Jamkesda), Bantuan Siswa Miskin (BSM) di bidang pendidikan dan program-program lainnya dalam rangka pengentasan kemiskinan. Ada pula program yang menjadi kontroversi, yaitu program cash assistant, yaitu Bantuan Langsung Tunal (BLT). Namun demikian upaya-upaya yang dilakukan pemerintah tersebut belum membuahkan hasil sebagaimana yang diharapkan, kemiskinan masih menyisakan berbagai persoalan yang perlu terus difikirkan dan diupayakan

Upaya pengentasan kemiskinan di Kota Banjar sempat terhambat dengan meningkatnya penduduk miskin sebagai akibat kenaikan bahan bakar minyak (BBM) sebanyak 2 (dua) kali pada tahun 2005, dimana berdampak cukup serius terhadap merosotnya tingkat kesejahteraan masyarakat lapisan bawah. Menurut Irawan (1998), penurunan tajam pada pendapatan telah menyebabkan banyak rumah tangga miskin makin nestapa karena mengalami kesulitan untuk membeli makanan (BPS, 2008:3).

Sesuai tujuannya, kegiatan pelatihan keterampilan berusaha dan bantuan stimulan usaha ekonomis produktif bagi keluarga miskin diduga mampu memberikan pengaruh terhadap pengentasan kemiskinan di Kota Banjar. Namun demikian untuk menunjang pengembangan program/kegiatan tersebut dalam rangka penanggulangan kemiskinan di Kota Banjar, masih perlu dilakukan upaya-upaya pembaharuan baik model maupun strateginya sehingga diharapkan pada masa yang akan datang keluarga fakir miskin di Kota Banjar dapat mengentas.

\section{METODE PELAKSANAAN}

Pada penelitian ini penulis menggunakan metode penelitian survey dengan disain korelasional, yaitu mencari hubungan antara varabel bebas dan variabel terikat, dimana semua variabel yang dipelajari terlebih dahulu dideskripsikan dan selanjutnya dikorelasikan antara variabel bebas dengan variabel terikat.

Operasionalisasi variabel penelitian adalah sebagai berikut:

Pelatihan keterampilan berusaha adalah kegiatan yang bertujuan untuk meningkatkan kemampuan praktis berusaha yang disesuaikan dengan minat dan ketrampilan KBS serta kondisi wilayah, termasuk kemungkinan pemasaran dan pengembangan hasil usahanya. Nilai tambah lain dari pelatihan adalah tumbuhnya rasa percaya diri dan harga diri KBS untuk mengatasi permasalahan yang dihadapi dan memperbaiki kondisi kehidupannya

Bantuan stimulan UEP adalah modal kerja atau berusaha yang disesuaikan dengan keterampilan KBS dan kondisi setempat. Bantuan ini merupakan hibah (bukan pinjaman atau kredit) akan tetapi diharapkan bagi KBS penerima bantuan untuk mengembangkan dan menggulirkan kepada warga masyarakat lain yang perlu dibantu. 
Kemiskinan mencakup antara lain ketidakmampuan memenuhi kebutuhan dasar (sandang, pangan, papan); tidak memiliki akses terhadap kebutuhan kesehatan; pendidikan, sanitasi air bersih; tidak adanya jaminan masa depan; kerentanan terhadap gonjangan yang sifatnya individual maupun massal; rendahnya sumberdaya alam; tidak adanya akses terhadap lapangan kerja dan mata pencaharian yang berkesinambungan.

Untuk mengetahui hubungan fungsional antara variabel digunakan metode regresi. Regresi yang digunakan yaitu Regresi Linier Sederhana dan Regresi Linier Ganda

\section{HASIL DAN PEMBAHASAN}

\section{Efektifitas Pelatihan Keterampilan Berusaha dalam Pengentasan Kemiskinan}

Berdasarkan hasil pengujian regresi linier nilai $\mathrm{R}$ (korelasi) dan koefisien determinasi $\left(\mathrm{R}^{2}\right)$ yang digunakan sebagai alat analisis untuk menunjukkan besarnya kontribusi dari variabel independent $\left(\mathrm{X}_{1}\right)$ dapat menjelaskan variabel dependent ( $\mathrm{Y}$ ) diperoleh nilai $\mathrm{R}$ sebesar 0,905 yang menunjukkan bahwa terdapat pengaruh yang kuat program pelatihan keterampilan berusaha bagi keluarga miskin terhadap pengentasan kemiskinan di Kota Banjar. Selanjutnya nilai koefisien determinasi $\left(\mathrm{R}^{2}\right)$ sebesar 0,820 hal ini berarti $82 \%$ variabel pengentasan kemiskinan dipengaruhi oleh program pelatihan keterampilan berusaha bagi keluarga miskin.

Secara umum pelatihan merupakan bagian dari pendidikan yang menggambarkan suatu proses dalam pengembangan organisasi maupun masyarakat. Pendidikan dengan pelatihan merupakan suatu rangkaian yang tak dapat dipisahkan dalam sistem pengembangan sumberdaya manusia, yang di dalamnya terjadi proses perencanaan, penempatan, dan pengembangan tenaga manusia.

Dalam proses pengembangannya diupayakan agar sumberdaya manusia dapat diberdayakan secara maksimal, sehingga apa yang menjadi tujuan dalam memenuhi kebutuhan hidup manusia tersebut dapat terpenuhi. Moekijat (1993:3) juga menyatakan bahwa "pelatihan adalah suatu bagian pendidikan yang menyangkut proses belajar untuk memperoleh dan meningkatkan keterampilan diluar sistem pendidikan yang berlaku, dalam waktu yang relatif singkat dan dengan metode yang lebih mengutamakan praktek daripada teori”. Pernyataan ini didukung Yoder (1962:368) yang mendefinisikan kalau kegiatan pelatihan sebagai upaya mendidik dalam arti sempit, terutama dilakukan dengan cara instruksi, berlatih, dan sikap disiplin. Antara pendidikan dengan pelatihan sulit untuk menarik batasan yang tegas, karena baik pendidikan umum maupun pelatihan merupakan suatu proses kegiatan pembelajaran yang mentransfer pengetahuan dan keterampilan dari sumber kepada penerima.

Dengan pelatihan juga dapat menimbulkan perubahan dalam kebiasaan-kebiasaan bekerja masyarakat, perubahan sikap terhadap pekerjaan, serta dalam informasi dan pengetahuan yang mereka terapkan dalam pekerjaannya sehari-hari. Kegiatan pelatihan dapat terjadi apabila seseorang atau masyarakat menyadari perlunya mengembangkan potensi dan kemampuan dalam memenuhi kebutuhan maupun kepuasan hidupnya, oleh sebab itu diperlukan kegiatan pemberdayaan. Pemberdayaan menunjuk kepada kemampuan orang, khususnya kelompok yang kurang beruntung, rentan dan lemah sehingga mereka memiliki kekuasaan dan kemampuan dalam: (1) memenuhi kebutuhan dasarnya sehingga mereka memiliki kebebasan dalam arti bebas dari ketidakberdayaan, kelaparan dan kesakitan, dan (2) menjangkau sumber-sumber produktif yang memungkinkan mereka dapat meningkatkan pendapatannya dan memperoleh barang-barang dan jasa-jasa yang mereka perlukan serta berperanserta dalam pembangunan. Pemberdayaan dapat dimaknai sebagai upaya melepaskan belenggu kemiskinan melalui pertumbuhan ekonomi dan keterbelakangan melalui pendidikan. Kegiatan pemberdayaan yang dilakukan melalui pelatihan bertujuan untuk memperkuat posisi seseorang 
melalui penumbuhan kesadaran dan kemampuan individu yang bersangkutan, mengidentifikasi persoalan yang dihadapi dan memikirkan langkah-langkah mengatasinya.

Dengan demikian, kegiatan pelatihan lebih ditekankan pada peningkatan pengetahuan, keahlian/ keterampilan (skill), pengalaman, dan sikap peserta pelatihan tentang bagaimana melaksanakan aktivitas atau pekerjaan tertentu. Hal ini sejalan dengan pendapat Henry Simamora (1995:287) yang menjelaskan bahwa "pelatihan merupakan serangkaian aktivitas yang dirancang untuk meningkatkan keahlian, pengetahuan, pengalaman ataupun perubahan sikap seorang individu atau kelompok dalam menjalankan tugas tertentu."Pengertian pelatihan antara satu rumusan dengan rumusan lain pada umumnya tidak bertentangan, melainkan memiliki ciri atau unsur yang sama. Dalam suatu pelatihan memiliki beberapa ciri, yaitu: (a) direncanakan dengan sengaja, (b) adanya tujuan yang hendak dicapai, (c) ada peserta (kelompok sasaran) dan pelatihan, (d) ada kegiatan pembelajaran secara praktis, (e) isi belajar dan berlatih menekankan pada keahlian atau keterampilan suatu pekerjaan tertentu, (f) dilaksanakan dalam waktu relatif singkat, dan (g) ada tempat belajar dan berlatih. Berdasarkan beberapa ungkapan tentang pengertian dan tujuan pelatihan serta ciri-ciri yang digambarkan dalam suatu pelatihan tersebut, maka pelatihan dapat diartikan sebagai suatu upaya melalui proses pembelajaran yang bertujuan untuk meningkatkan pengetahuan, keterampilan, dan sikap seseorang atau sekelompok orang dalam suatu tugas pekerjaan tertentu dan dilaksanakan dalam waktu relatif singkat pada tempat tertentu.

Pelatihan keterampilan usaha dalam pembelajarannya lebih berorientasi pada praktek atau aplikasi praktis, memiliki kecenderungan yang sesuai dengan kebutuhan warga masyarakat. Apalagi dalam pelatihan keterampilan usaha yang menekankan keterlibatan peserta pelatihan dalam belajarnya, maka akan membuat peserta pelatihan secara aktif terlibat dalam proses pembelajaran dan dalam pengambilan keputusan. Keterlibatan warga belajar dalam setiap proses kegiatan belajar sesuai dengan ungkapan Knowles (1980), bahwa peserta belajar terutama bagi orang dewasa, proses belajarnya harus dilaksanakan dengan melibatkan partisipasi aktif dari warga belajarnya. Pendekatan semacam ini akan menjadikan suatu pengalaman yang berarti bagi peserta atau warga belajar itu sendiri. Sebagaimana dikemukakan John Dewey dengan konsep "Learning by doing-nya" yang dalam salah satu isi pembelajarannya mengutamakan bidang keterampilan yang dirasa berguna dalam kehidupan dan langsung dapat dirasakan oleh masyarakat.

Pelatihan keterampilan usaha dapat dipandang sebagai upaya memperbaiki kualitas atau meningkatkan kemampuan warga masyarakat dalam bekerja untuk memenuhi kebutuhan hidupnya, terutama dalam rangka mengimbangi dampak sosial akibat berbagai kebijakan yang mempersempit lapangan pekerjaan bagi masyarakat.

Pelatihan ketrampilan berusaha, dimaksudkan untuk meningkatkan kemampuan praktis berusaha yang disesuaikan dengan minat dan ketrampilan penyandang masalah kesejahteraan sosial (PMKS) serta kondisi wilayah, termasuk kemungkinan pemasaran dan pengembangan hasil usahanya.

Mempertahankan kerjasama yang sudah terbangun antara para anggota organisasi sehingga dalam program yang dijalankan mendapat suatu dampak positif bagi masyarakat guna terwujutnya program pengentasan kemiskinan yang ada pada masyarakat Indonesia. Profesionalisme para anggota organisasi sangat di pentingkan guna memperlancar kinerja organisasi, dalam mengurus serta mengelola KUBE perlu memiliki catatan atau administrasi yang baik, yang mengatur keanggotaan, organisasi, kegiatan, keuangan, pembukuan dan lain sebagainya agar dalam mementukan tujuan dari program tersebut tepat pada sasaran.

2. Efektifitas Bantuan Stimulan Usaha Ekonomis Produktif Dalam Pengentasan 
Regresi linier nilai $\mathrm{R}$ (korelasi) dan koefisien determinasi $\left(\mathrm{R}^{2}\right)$ yang digunakan sebagai alat analisis untuk menunjukkan besarnya kontribusi dari variabel independent $\left(\mathrm{X}_{2}\right)$ dapat menjelaskan variabel dependent (Y) diperoleh nilai $\mathrm{R}$ sebesar 0,908 yang menunjukkan bahwa terdapat pengaruh yang kuat program bantuan stimulan usaha ekonomis produktif bagi keluarga miskin terhadap pengentasan kemiskinan di Kota Banjar. Selanjutnya nilai koefisien determinasi $\left(R^{2}\right)$ sebesar 0,824 hal ini berarti $82,4 \%$ variabel pengentasan kemiskinan dipengaruhi oleh program bantuan stimulan usaha ekonomi produktif bagi keluarga miskin.

Untuk mengatasi permasalahan kemiskinan tersebut perlu adanya program yang efektif, efisien, terpadu dan berorientasi pada kemandirian dan berkelanjutan. Karena adopsi sistem penanggulangan kemiskinan secara statis, melalui program kompensasi; bantuan langsung pangan, voucher pelayanan minimum kesehatan dan pendidikan, hanya dapat memecahkan persoalan kemiskinan jangka pendek (World Development Report, 2004). Mengingat ketika program telah berakhir, masyarakat miskin masih tetap memerlukannya. Masih tingginya jumlah penduduk miskin dewasa ini membuat Pemerintah terpaksa harus bekerja keras untuk mewujudkan target tersebut. Apalagi dalam situasi inflasi sekarang yang mengakibatkan daya beli masyarakat cenderung turun, upaya pengentasan kemiskinan menjadi suatu pekerjaan yang bersifat urgen dan harus segera dilaksanakan.

Kemiskinan merupakan suatu masalah yang ada sudah sejak lama dan hampir bisa dikatakan akan tetap menjadi "kenyataan abadi" dalam kehidupan. Pengertian kemiskinan sendiri sebagai suatu konsep ilmiah yang lahir sebagai dampak ikutan dari istilah pembangunan. Karena itu dalam setiap pembahasan tentang pembangunan, maka pembahasan kemiskinan mendapatkan tempat yang cukup penting. Pada tahap ini, kemiskinan dipandang sebagai bagian dari masalah dalam pembangunan yang keberadaannya ditandai oleh adanya pengangguran, keterbelakangan, yang kemudian meningkat menjadi ketimpangan. Secara bersamaan, kenyataan tersebut bukan saja menimbulkan tantangan tersendiri, tetapi juga memperlihatkan adanya suatu mekanisme dan proses yang tidak beres dalam pembangunan.

Masyarakat miskin umumnya lemah dalam kemampuan berusaha dan terbatas aksesnya kepada kegiatan ekonomi, sehingga tertinggal jauh dari masyarakat lainnya yang mempunyai potensi lebih tinggi. Masalah kemiskinan muncul karena adanya sekelompok anggota masyarakat yang secara struktural tidak mempunyai peluang dan kemampuan yang memadai untuk mencapai tingkat kehidupan yang layak. Akibatnya mereka harus mengakui keunggulan kelompok masyarakat lainnya dalam persaingan mencari nafkah dan pemilikan aset produksi sehingga semakin lama semakin tertinggal. Dalam prosesnya, gejala tersebut memunculkan persoalan ketimpangan distribusi pendapatan.

Pemberian bantuan stimulan usaha ekonomis produktif pada hakekatnya merupakan bantuan modal kerja sebagai sarana/prasarana pendukung usaha (modal usaha) bagi keluarga miskin dalam melaksanakan aktivitasnya untuk meningkatkan taraf kehidupannya. Pemberian bantuan pada dasarnya ini disesuaikan dengan keterampilan penyandang masalah kesejahteraan sosial (PMKS) dan kondisi setempat. Bantuan ini merupakan hibah (bukan pinjaman atau kredit) akan tetapi diaharapkan bagi penyandang masalah kesejahteraan sosial (PMKS) penerima bantuan untuk mengembangkan dan menggulirkan kepada warga masyarakat lain yang perlu dibantu karena masih banyak masyarakat yang sangat membutuhkan bantuan serta kinerja dari organisasi yang tujuannya untuk memberantas kemiskinan dan bisa keluar dari keterpurukan yang di alami oleh masyarakat.

\section{Efektifitas Pelatihan Keterampilan Berusaha dan Bantuan Stimulan Usaha Ekonomis Produktif Dalam Pengentasan Kemiskinan.}

Berdasarkan hasil pengujian regresi linier nilai $\mathrm{R}$ (korelasi) dan koefisien determinasi $\left(\mathrm{R}^{2}\right)$ 
yang digunakan sebagai alat analisis untuk menunjukkan besarnya kontribusi dari variabel independent $\left(\mathrm{X}_{1}\right.$ dan $\left.\mathrm{X}_{2}\right)$ dapat menjelaskan variabel dependent $(\mathrm{Y})$ diperoleh nilai $\mathrm{R}$ sebesar 0,943 yang menunjukkan bahwa terdapat pengaruh yang kuat program pelatihan keterampilan berusaha dan bantuan stimulan usaha ekonomis produktif bagi keluarga miskin terhadap pengentasan kemiskinan. Selanjutnya nilai koefisien determinasi $\left(\mathrm{R}^{2}\right)$ sebesar 0,889 hal ini berarti 88,9 \% variasi dari pengentasan kemiskinan dipengaruhi oleh program pelatihan keterampilan berusaha dan bantuan stimulan usaha ekonomis produktif bagi keluarga miskin.

Peran lembaga keuangan dalam pengembangan dan pelestarian bantuan adalah ; pertama, mempersiapkan terciptanya akses atau kesempatan bagi masyarakat dalam memperoleh bantuan. Kedua, mempersiapkan masyarakat lapisan bawah untuk dapat mendayagunakan bantuan tersebut sehingga dapat menjadi modal bagi kegiatan usaha. Ketiga, menanamkan pengertian bahwa bantuan yang diberikan harus dapat menciptakan akumulasi modal dari suplus yang diperoleh dari kegiatan sosial ekonomi.

Unit Pengelola Keuangan (UPK) di tingkat desa maupun kecamatan perlu dibentuk untuk mengoptimalkan pengelolaan dana bantuan. Pengelolaannya dapat dilakukan sendiri oleh anggota masyarakat. UPK yang sudah ada dan berkembang dalam Program Pengembangan Kecamatan (PPK) perlu dipertajam dan diperluas fungsi dan perannya. Fungsi UPK tidak hanya sebagai lembaga pengepul dana bantuan tetapi harus dapat benar-benar berfungsi sebagai lembaga yang dapat mengelola keuangan dengan memberikan bantuan stimulan dana sebagai modal yang dapat bergulir kepada kelompok masyarakat. Sehingga apabila program pembangunan tersebut selesai maka lembaga UPK itu tetap terus berfungsi menggulirkan dananya kepada pokmas yang lain.

UPK ini berperan sebagai lembaga keuangan milik masyarakat yang dapat menampung dan mengelola berbagai program pembangunan yang masuk ke daerah. Sehingga berbagai program pembangunan yang masuk ke daerah, dananya dapat langsung dikontrol dengan mudah oleh masyarakat itu sendiri. Dengan demikian kebocoran-kebocoran dana bantuan program pembangunan dapat diminimalisir bahkan dapat dihilangkan. Kontrol Publik ini merupakan upaya yang sangat efektif dalam mengantisipasi segala kemungkinan kebocoran dalam pengelolaan program-program pembangunan di daerah.

UPK ini dapat berkembang menjadi lembaga keuangan alternatif milik masyarakat yang tumbuh dari masyarakat sendiri. Lembaga keuangan ini dapat menjadi embrio lembaga keuangan dengan prinsip-prinsip perbankan yang pelaksanaannya dengan menerapkan prinsipprinsip kebersamaan (kooperatif). Dalam perkembangan selanjutnya lembaga keuangan ini dapat berbadan hukum misalnya seperti koperasi. Pengembangan kegiatan sosial ekonomi masyarakat ini diprioritaskan pada masyarakat miskin di desa tertinggal, yaitu berupa peningkatan kualitas sumber daya manusia, dan peningkatan permodalan yang didukung sepenuhnya dengan kegiatan pelatihan yang terintegrasi sejak dari kegiatan penghimpunan modal, penguasaan teknik produksi, pemasaran hasil dan pengelolaan surplus usaha. Kegiatan ini perlu diarahkan agar bantuan dana yang diberikan kepada daerah khususnya masyarakat miskin di desa tertinggal dapat meningkatkan kapasitas masyarakat melalui pemupukan modal yang bersumber dari surplus yang dihasilkan dan yang pada gilirannya dapat menciptakan pendapatan yang dinikmati oleh masyarakat.

$\begin{array}{ccr}\text { Dalam } & \begin{array}{c}\text { kerangka } \\ \text { perencanaan } \\ \text { pembangunan, }\end{array} & \text { upayangulangan }\end{array}$
kemiskinan perlu dikaitkan dengan peningkatan kapasitas masyarakat sebagai dasar pemupukan modal. Peningkatan kapasitas masyarakat dapat dilakukan melalui pemberian bantuan dana secara stimulan sebagai modal usaha, pelatihan yang tepat, penerapan teknologi tepat guna, pembangunan prasarana pendukung, penyediaan sarana penunjang, dan penguatan kelembagaan sebagai wadah usaha masyarakat. Dalam 
kerangka pemupukan modal, berbagai bantuan baik yang diberikan oleh pemerintah maupun masyarakat yang sudah maju, perlu ditempatkan sebagai pemacu proses perubahan dalam kegiatan sosial ekonomi masyarakat menuju pada suatu kehidupan yang lebih maju.

Pemupukan modal merupakan dasar pengembangan ekonomi rakyat dalam proses transformasi struktural menuju pada masyarakat maju dan berkembang. Pemahaman tentang aspek keuangan yang benar perlu ditanamkan kepada setiap pelaku ekonomi di setiap lini tingkatan. Pemahaman tentang pengelolaan keuangan merupakan dasar dari pemupukan modal ekonomi rakyat. Unit Pengelola Keuangan yang diperkenalkan melalui Program Pengembangan Kecamatan (PPK) perlu dipertajam sebagai upaya penaggulangan kemiskinan. UPK ini harus benar-benar dapat berfungsi mengelola bantuan dengan memutarkan dananya ke masyarakat dengan memberikan modal usaha secara stimulan untuk dapat mengembangkan kehidupan sosial ekonominya. Kontrol publik dapat dilakukan oleh masyarakat secara langsung dengan mengoptimalkan UPK sebagai lembaga keuangan milik masyarakat untuk menampung dan mengelola bantuan dana dari berbagai program pembangunan yang masuk ke desa maupun kecamatan sehingga penggunaan bantuan dana pembangunan dilakukan secara transparan dan bertanggung jawab. Terwujudnya lembaga keuangan yang muncul dari prakarsa masyarakat, dikelola oleh masyarakat dan hasilnya dinikmati oleh masyarakat sendiri tentu keberhasilannya dapat dilestarikan dan ditumbuhkembangkan di daerah lain. Peran pemerintah diharapkan dapat menciptakan peluang dan kesempatan usaha yang lebih besar bagi masyarakat miskin. Dalam tataran mikro, model pemberdayaan sebagai dasar penanggulangan kemiskinan yang telah dikembangkan oleh kalangan lembaga swadaya masyarakat, perguruan tinggi, dan organisasi kemasyarakatan, sangat efektif untuk menjembatani upaya yang dilakukan melalui berbagai program pembangunan. Dimensi kemiskinan yang begitu luas mengharuskan setiap upaya penanggulangan kemiskinan dalam tataran makro perlu dilakukan secara terpadu yang meliputi berbagai program pembangunan baik sektoral maupun regional. Dalam hal ini yang diperlukan penajaman program dan kegiatan sehingga hasilnya lebih optimal dan dampaknya langsung dapat dirasakan oleh masyarakat miskin.

\section{Model atau strategi yang dapat dikembangkan dalam pengentasan kemiskinan di Kota Banjar}

Penanggulangan kemiskinan perlu dilakukan secara bertahap, terus menerus dan terpadu yang didasarkan pada kemandirian yaitu meningkatkan kemampuan penduduk yang miskin untuk menolong diri mereka sendiri. Hal ini berarti pemberian kesempatan yang luas bagi penduduk miskin untuk melakukan kegiatan sosial ekonomi yang produktif sehingga mampu menghasilkan nilai tambah yang lebih tinggi dan pendapatan yang lebih besar. Pemberian kesempatan dan peningkatan kemampuan penduduk miskin menyangkut kemudahan untuk memperoleh sumber daya, mendayagunakan kemajuan teknologi, memanfaatkan pasar secara terus menerus, serta mendapatkan layanan dari berbagai sumber pembiayaan.

Kemiskinan yang harus ditanggulangi mencakup permasalahan pembangunan di berbagai bidang yang mencakup banyak aspek. Pemilikan sumber daya yang tidak merata, kemampuan masyarakat yang tidak seimbang, dan ketidaksamaan kesempatan dalam menghasilkan akan menyebabkan keikutsertaan dalam pembangunan tidak merata. Ini semua pada gilirannya menyebabkan perolehan pendapatan tidak seimbang, dan kemudian, menimbulkan struktur masyarakat yang timpang. Perbedaan struktur masyarakat yang telah ikutserta dalam proses pembangunan dengan yang masih tertinggal menyebabkan keadaan kesenjangan atau kemiskinan struktural. Permasalahan itu harus dapat ditangani secara menyeluruh, seksama, dan bertahap agar tidak menjurus pada kecemburuan dan gejolak sosial 
yang dapat mengganggu kelancaran dan kessinambungan pembangunan.

Upaya penanggulangan kemiskinan Indonesia telah dilakukan dan menempatkan penanggulangan kemiskinan sebagai prioritas utama kebijakan pembangunan nasional. Kebijakan kemiskinan merupakan prioritas Rencana Pembangunan Jangka Menengah (RPJM) 2004-2009 dan dijabarkan lebih rinci dalam Rencana Kerja Pemerintah (RKP) setiap tahun serta digunakan sebagai acuan bagi kementrian, lembaga dan pemerintah daerah dalam pelaksanaan pembangunan tahunan.

Sebagai wujud gerakan bersama dalam mengatasi kemiskinan dan mencapai Tujuan pembangunan Milenium, Strategi Nasional Pembangunan Kemiskinan (SPNK) telah disusun melalui proses partisipatif dengan melibatkan seluruh stakeholders pembangunan di Indonesia. Selain itu, sekitar $60 \%$ pemerintah kabupaten/ kota telah membentuk Tim Penanggulangan Kemiskinan Daerah (TPKD) dan menyusun Strategi Penanggulangan Kemiskinan Daerah (SPKD) sebagai dasar utama dalam penanggulangan kemiskinan di daerah dan mendorong gerakan sosial dalam mengatasi kemiskinan.

Adapun langkah jangka pendek yang diprioritaskan antara lain sebagai berikut:

a. Mengurangi kesenjangan antar daerah dengan; (i) penyediaan sarana-sarana irigasi, air bersih dan sanitasi dasar terutama daerah-daerah langka sumber air bersih. (ii) pembangunan jalan, jembatan, dan dermaga daerah-daerah tertinggal. (iii) redistribusi sumber dana kepada daerah-daerah yang memiliki pendapatan rendah dengan instrumen Dana Alokasi Khusus (DAK) .

b. Perluasan kesempatan kerja dan berusaha dilakukan melalui bantuan dana stimulan untuk modal usaha, disamping pelatihan keterampilan kerja dan meningkatkan investasi serta revitalisasi industri.

c. Dalam pemenuhan sarana hak dasar penduduk miskin diberikan pelayanan antara lain (i) pendidikan gratis sebagai penuntasan program belajar 9 tahun termasuk tunjangan bagi murid yang kurang mampu (ii) jaminan pemeliharaan kesehatan gratis bagi penduduk miskin di puskesmas dan rumah sakit kelas tiga.

d. Khusus guna menunjang program yang sudah ada dalam rangka pengentasan kemiskinan di Kota Banjar, disamping melaksanakan strategi pemberdayaan masyarakat berupa program pelatihan keterampilan berusaha dan bantuan stimulan usaha ekonomis produktif, juga dapat dikembangkan strategi lain berupa pengembangan jejaring kerjasama (kemitraan), baik dengan instansi terkait, dunia usaha maupun pelaku-pelaku usaha lainnya. Hal ini dilaksanakan melalui pola Kelompok Usaha Bersama (KUBE) dimana anggota-anggotanya adalah mereka yang telah mengikuti pelatihan keterampilan berusaha dan bantuan stimulan usaha ekonomis produktif.

\section{SIMPULAN DAN SARAN \\ Simpulan}

Berdasarkan analisis hasil penelitian pengaruh program pelatihan keterampilan berusaha dan bantuan usaha ekonomis produktif bagi keluarga miskin terhadap pengentasan kemiskinan (studi pada program pemerintah dalam penanggulangan kemiskinan di Kota Banjar), dapat ditarik kesimpulan sebagai berikut:

1. Hasil pengujian secara parsial yang dilakukan ternyata program pelatihan keterampilan berusaha bagi keluarga miskin berpengaruh secara nyata terhadap pengentasan kemiskinan. Hal tersebut berdasarkan kriteria pengujian diperoleh kesimpulan adanya taraf signifikansi.

2. Hasil pengujian secara parsial yang dilakukan ternyata program bantuan usaha ekonomis produktif bagi keluarga miskin berpengaruh secara nyata terhadap pengentasan kemiskinan. Hal tersebut 
berdasarkan kriteria pengujian diperoleh kesimpulan adanya taraf signifikansi.

3. Hasil pengujian secara parsial yang dilakukan ternyata program pelatihan keterampilan berusaha dan bantuan usaha ekonomis produktif bagi keluarga miskin berpengaruh secara nyata terhadap pengentasan kemiskinan. Hal tersebut berdasarkan kriteria pengujian diperoleh kesimpulan adanya taraf signifikansi.

4. Dalam pengentasan kemiskinan, pemerintah telah menggulirkan beberapa program dan kebijakan terutama dalam mengurangi jumlah penduduk miskin, diantaranya pendidikan gratis sebagai penuntasan program belajar 9 tahun termasuk tunjangan bagi murid yang kurang mampu, jaminan pemeliharaan kesehatan gratis bagi penduduk miskin di puskesmas dan rumah sakit kelas tiga. Salah salah satu kebijakan Pemerintah Kota Banjar dalam pemberdayaan keluarga miskin adalah melalui program pelatihan keterampilan berusaha dan bantuan stimulan usaha ekonomis produktif (UEP). Guna mendukung dan kesimbungan program ini perlu dikembangkan terus model/strategi dalam pengentasan kemiskinan sehingga pada gilirannya mereka dapat menjadi masyarakat yang mandiri. dan terentas dari kemiskinan.

\section{Saran}

Berdasarkan kesimpulan yang telah dikemukakam serta permasalahan-permasalahan yang ditemukan, maka peneliti menyampaikan beberapa saran, diantaranya:

1. Upaya penanggulangan kemiskinan di era otonomi daerah, maka perlu diberikan peluang dan kesempatan yang sebesarbesarnya bagi keluarga fakir miskin untuk bisa berdaya dan belajar dalam mengatasi masalahnya secara mandiri sesuai motto pekerjaan sosial " to help people to help them selves".

2. Dalam pemberdayaan keluarga fakir miskin, pendamping sosial mempunyai peranan yang cukup penting dan strategis sebagai ujung tombak bagi keberhasilan program pengentasan kemiskinan, untuk itu agar mereka dapat menjalankan peran dan fungsinya secara optimal, disamping penguasaan dan pemahaman tentang masalah kemiskin, perlu juga dibekali pengetahuan dan keterampilan dalam pengeloaan usaha ekonomis produktif dan pembekalan dengan menggunakan praktek magang pada Kelompok Usaha Bersama (KUBE) Program Pemberdayaan Fakir Miskin yang sudah maju.

3. Untuk melihat perkembangan mereka (keluarga fakir miskin) yang telah memperoleh program pelatihan keterampilan berusaha dari Pemerintah Kota Banjar, maka perlu dilaksanakan monitoring secara koninue yang dilaksanakan secara berjenjang dalam rangka penguatan sosial bagi keluarga binaan socias (KBS) yang telah memperoleh pelatihan keterampilan berusaha dan bantuan stimulant usaha ekonomis produktif dari Pemerintah KotaBanjar.

\section{DAFTAR PUSTAKA}

Abdullah, M. Natsir. 2008. Analisis Kebijakan Publik Dalam Penanggulangan Masalah Kemiskinan, Jakarta . SINAR Departemen Sosial.

Ala, Andre Bayo. 2001. Kemiskinan dan Strategi Memerangi Kemiskinan, Yogyakarta. Liberty.

Arief, $\quad$ Saeful, 2000.

Menolak

Pembangunanisme, Yogyakarta, Pustaka Pelajar.

Arikunto, Suharsimi. 2004. Prosedur Penelitian Suatu Pendekatan Praktek, Jakarta. Rineka Cipta.

BPS dan Departemen Sosial. 2002. Penduduk Fakir Miskin Indonesia, Jakarta. Badan Pusat Statistik

BPS dan Bapeda Kota Banjar. 2009. Penduduk Miskin dan Indeks Kemahalan Kontruksi Kota Banjar Tahun 2008, Banjar. Badan Pusat Statistik. 
Bapeda-BPS Kota Banjar. 2009. Banjar Dalam Angk, Banjar. Bapeda-BPS.

Departemen Sosial. 1997. Pedoman Pembinaan dan Penumbuhan Kelompok Usaha Bersama (KUBE), Jakarta. Depsos.

Dewanta, Awan Setya, Editor. 1995. Kemiskinan dan Kesejagan di Indonesia, Yogyakarta. Aditya Media.

Hadwigeno dan Pahpahan. 1993. Identifikasi Wilayah Miskin di Indonesia Primus (3), Jakarta. LP3ES.

Ismaun. 2003. Peran Lembaga Mikro, Yogyakarta. IIEB FE UGM.

Juoro, Imam. 1985. Masalah Terdepan Dalam Pembangunan Indonesia, Bandung. Alumni.

Kartasasmita, Ginjanr, 1996. Pembangunan Untuk Rakyat Memadukan Pertumbuhan dan Pemerataan, Jakarta. CIDES.

Kuncoro, Mudrajad. 2000. Ekonomi Pandangan,

Teori Masalah dan Kebijakan, Yogyakarta . UPP AMP YKPN.

Lembaga Administrasi Negara RI. 2007. Kajian kebijakan Publik, Jakarta. LAN RI.

Lfe, Jim. 1995. Community Development: Creating Community Alternatrives, Vision, Analysis and Practice, Australia. .Longman.

Moekijat. 1993. Evaluasi Pelatihan Dalam Rangka Peningkatan Produktivitas, Bandung. Mandar Majau.

Nasution. 1995. Azas-Azas Kurikulum Edisi, Jakarta. Bina Aksara.

Nazir, Moh. 1998. Metode Penelitian, Jakarta. Ghalia Indonesia.

Poerwadarminta, JS.1984. Kamus Umum Bahasa Indonesia, Jakarta. Balai Pustaka.

Salim, Emil, 1984. Perencanaan Pembangunan dan Pemerataan Pendapatan, Jakarta. Inti Idayu Press.

Setyawan, Anton Agus. 2001. Kemiskinan di Dunia Ketiga Perspektif Ekonomi Politik Indonesia, Surakarta. Balai Penelitian dan Pengembangan FE UMS.
SMERU, 2000. Laporan Hasil Kajian Kemiskinan Partisipatif, Jakarta SMERU.

Soetrisno, R, 2001. Pemberdayaan Masyarakat dan Upaya Pembebasan Kemiskinan, Yogyakarta. Kanisius.

Sudjana. 1992. Metode Statistika, Bandung. Itarsito.

Sugiyono. 2000. Statistik Untuk Penelitian, Bandung. Alfabeta.

Suharto, Edi. 1997. Pembangunan, KebijakanSosial dan Pekerjaan Sosial, Bandung LSP-STKS.

2005. Membangun Masyarakat Memberdayakan Masyarakat, Bandung PT. Refika Aditama.

--------, 2007. Meretas Kebijakan Pro Poor: Mengagas Pelayanan Sosial Yang Berkeadilan, Bandung Sekolah Tinggi Kesejahteraan Sosial (STKS).

Sumardjan, Selo, 1980. Kemiskinan Struktural dan Pembangunan Kata Pengantar dalam Alfian (at. Al), Kemiskinan Struktural, Suatu Bunga Rampai, Jakarta, YIIS.

Sumodinsingrat, Gunawan. 1997. Pembangunan Daerah dan Pemberdayaan Masyarakat, Jakarta. PT. Bina Rena Pariwara.

2001. Responsi Terhadap Kesejangan Ekonomi, Jakarta. Perpod. -, 2008. Kemitraan Kunci Menuju Rakyat Sejahtera, Jakarta. SINARDepartemen Sosial.

Suparlan, Parsudi, Penyunting. 1995. Kemiskinan Di Perkotaan, Jakarta. Yayasan Obor Indonesia.

Surakhman, Wardiman. 1995. Pengentasan Penelitian Ilmiah, Bandung.Tarsito.

Suryana, 2003. Kewirausahaan, Jakarta. Salemba Empat.

Suwondo, Kutu, 1998. Struktur Sosial dan Kemiskinan, Salatiga. Yayasan Bina Dharma. 
Suyanto, Bagong dan Sutinah (Editor), 2008. Metode Penelitian Sosial: Berbagai Alternatif Pendekatan, Jakarta, Kencana Perdana Group.

Syahrir. 1988. Pembangunan Berdimensi Kerakyatan, Jakarta. Yayasan Obor Indonesia.

Syahyuti. 2006. 30 Konsep Penting dalam Pembangunan Perdesaan dan Perkotaan, Jakarta. Bina Perwira.

Tilaar, H.A.R. 1997. Pengembangan Sumber Daya Manusia Di Era Globalisasai. Jakarta. Grisindo.

Wasistiono, Sadu. 2006. Prospek Pengembangan Desa, Bandung. Fokus Media.

Word Bank, 2000. Word Development Report 2000

Yoder. 1962. Personal Principle and Policies. Printing Hall, New York. Maurez Company Ltd.

\section{Peraturan-Peraturan}

Undang-Undang Dasar 1945 , Amandemen I IV
Undang-Undang Nomor 27 Tahun 2002 tentang Pembentukan Kota Banjar di Provinsi Jawa Barat

Undang-Undang Nomor 32 Tahun 2004 tentang Pemerintahan Daerah

Undang-Undang Nomor 11 Tahun 2009 tentang Kesejahteraan Sosial

Peraturan Pemerintah Nomor 42 Tahun 1981 tentang Pelayanan Kesejahteraan Sosial bagi Fakir Miskin

Peraturan Presiden Nomor 54 Tahun 2005 tentang Tim Koordinasi Penanggulangan Kemiskinan

Surat Keputusan Walikota Banjar Nomor: 460/Kpts.131-Huk/VII/2007 Tahun 2007 tentang Pembentukan Tim Koordinasi Penanggulangan Kemiskinan Daerah Kota Banjar 